\title{
'Because they believed': Students' ideas of historical empathy in Greek Cypriot primary education
}

\author{
Lukas Perikleous* - University of Cyprus, Cyprus
}

\begin{abstract}
What happened in the past is often the result of human behaviour (individual or collective) that was guided by certain ideas, beliefs and intentions, and influenced by the historical context in which it happened. It can be argued that understanding past behaviour is essential for historical understanding, and therefore students' ideas about making sense of people in the past are important for history education. This article reports on aspects of a broader qualitative study of students' and teachers' ideas of historical empathy. More specifically, the study explores participants' reasoning in terms of the ideas they use to explain the behaviour of groups of people in the past and the present. The sample was drawn from two urban primary schools in Nicosia, Cyprus; 68 students, aged between 8 and 12, and five history teachers in the sample classes participated in it. Pen-and-paper tasks, semi-structured interviews and classroom observations were used as data generation instruments. This article focuses on some of the findings of the analysis of students' responses to pen-and-paper tasks, which asked them to explain religious practices for the treatment of diseases used by two different groups in the past. These findings suggest the existence of ideas of historical empathy identified by previous studies. In this sense, they contribute to the existing evidence of the presence of these ideas in a variety of educational and cultural contexts.
\end{abstract}

Keywords: historical empathy; empathic explanations; students' ideas; types of explanations; primary education

\section{A troublemaker concept}

Talking about the beginnings of the Schools Council History Project, which transformed history education in England from the early 1970s by teaching the subject as a discipline requiring historical thinking and the use of sources, David Sylvester, the originator and first director of the project, referred to historical empathy as 'a word I brought into history teaching which caused me a lot of trouble, but nevertheless. It came into the words and it's been around in history teaching for a while' (Sheldon, 2009a: 10). In these lines, Sylvester provides an accurate account of the place of the concept of 'empathy' in history education during the last five decades. It is a term that instigated much controversy, and still does, but also a concept important enough to remain central in history education until today.

Much of the controversy surrounding historical empathy is due to a lack of consensus about the meaning of the term, which in turn leads to different ideas and even confusion about what empathizing, or having empathy, with people in the 
past entails and how the concept can be taught in history education. In the past, historical empathy was accused of being a multifaceted and ambiguous concept that promoted sympathy rather than understanding, and encouraged unhistorical approaches to history teaching by letting students imagine themselves in the past (Harris and Foreman-Peck, 2004; Knight, 1989; Low-Beer, 1989). Even Peter Lee and Denis Shemilt, two of the most prominent advocates of empathy in history education, argue that during the 1970s and 1980s the concept was often wrongly associated with imagination, sympathy and identification, and as a result 'much [of the teaching of empathy] ranged from the weak to the execrable' (Lee and Shemilt, 2011: 39). This led some authors to question the place of historical empathy in education (Knight, 1989; Low-Beer, 1989), while others argued that what was needed was to clarify the term in order to avoid confusion and misuse in classrooms (Boddington, 1980; Foster, 2001; Lee and Shemilt, 2011; Lee and Ashby, 2001).

The problem of terminology also led to the suggestion of other terms to describe the idea of understanding people in the past in history education (such as 'rational understanding' and 'perspective taking'). However, as several authors point out, these alternatives are also vulnerable to confusion and misuse (Barton and Levstik, 2004; Downey, 1995; Lee and Ashby, 2001). During the mid-1970s, David Sylvester himself, acknowledging that the use of the term 'empathy' could be problematic, considered a change in terminology. However, he could not come up with an alternative that would be immune to misconceptions (Shemilt, 2016). Peter Lee, who at some point wrote to Denis Shemilt saying 'for God's sake, don't use that word [empathy]' (Sheldon, 2009b: 17), also admits that despite his own concerns 'any word we could have used would have brought misunderstandings, so in the end I'm not too worried about the fact that it was empathy that got used because anything else would almost certainly have been equally bad' (ibid.: 18).

Despite the fact that an undisputed term cannot be agreed upon, there is still a need to clarify what the act of understanding people in the past entails. Attempting this clarification is not within the scope of this article. However, it is important to provide a description of how the concept is approached in the study reported here.

\section{The concept of empathy in this study}

For the purposes of this study, historical empathy is considered as both a cognitive act and a disposition. It is a cognitive act in the sense that historical empathy is about understanding past behaviour based on the knowledge of ideas, beliefs, intentions and feelings of people in the past, and also of the historical context in which they lived (Yeager and Foster, 2001; Lee and Ashby, 2001; Perikleous, 2014). An important part of this kind of understanding is the acknowledgement of the temporal and cultural distance that exists between us and people in the past. Our world and the world of the past are radically different, and past behaviour often cannot be explained by reference to our contemporary systems of beliefs and knowledge (Shemilt, 1984). As David Lowenthal (1985: xvi) puts it, 'However faithfully we preserve, however authentically we restore, however deeply we immerse ourselves in bygone times, life back then was based on ways of being and believing incommensurable with our own.' The only way to make sense of past behaviour is by knowing the logics of the world in which it took place (Sewell, 2005). In this sense, we need to seek for empathic explanations that identify rational and meaningful behaviours based on 'reasonably coherent and cohesive systems' of meaning (Shemilt, 1984: 48). It is also important to recognize that we are not standing on an Archimedean point, and therefore our empathic explanations 
are always influenced by our own perspective and context. As Barton and Levstik (2004: 219) put it, 'this is the recognition that our own perspectives depend on historical context: They are not necessarily the result of logical and dispassionate reason but reflect the beliefs we have been socialized into as members of cultural groups'.

Despite this distance between our world and the world of the past, they are connected by the fact that the inhabitants of the former (us) share a common humanity with the inhabitants of the latter (people in the past) (Shemilt, 1984). For example, although the mindsets of an ancient Mayan adult and a twenty-first century Cypriot primary school student are radically different, they are both human beings who are likely to want to be cured when they get sick. The two worlds are also developmentally connected in the sense that the present world is in fact the latest version (better or worse) of the world of the past (ibid.). Understanding these connections between us and people in the past (that is, changes and continuities in human societies) contributes to making sense of past behaviour.

Furthermore, this temporal and cultural distance, and the fact that our empathic explanations are influenced by 'our prior involvement in the world' (Retz, 2015: 224), should not be approached merely as an obstacle that we need to overcome, but also 'as the very factor that enables us to understand the historical other' (ibid.). In HansGeorg Gadamer's hermeneutics, this is the idea that historical understanding occurs when our own prejudices, which are the result of our prior involvement in the world (our historicity), are taken into consideration and become part of a conversation between us and the historical other. This process 'will make conscious the prejudices governing our own understanding, so that the text, as another's meaning, can be isolated and valued on its own' (Gadamer, 2004: 298). Becoming aware of our own prejudices is possible exactly because of the distance between us and them. As Gadamer (ibid.) explains:

Foregrounding (abheben) a prejudice clearly requires suspending its validity for us. For as long as our mind is influenced by a prejudice, we do not consider it a judgment. How then can we foreground it? It is impossible to make ourselves aware of a prejudice while it is constantly operating unnoticed, but only when it is, so to speak, provoked. The encounter with a traditionary text [a past behaviour] can provide this provocation. For what leads to understanding must be something that has already asserted itself in its own separate validity.

Although imagination can be a misleading notion when we think about historical empathy, and its misuse often leads to unsophisticated approaches, it remains an important component of understanding people in the past. Lee (1984: 85) points out that 'a good historian, it seems, must have imagination, and a mediocre one lacks it. Too much of it, however, and the result is not just a mediocre historian, but a downright bad one.' Although Lee is right to say that imagination can benefit or hinder historical thinking, we should not think of this issue as merely one of quantity. R.G. Collingwood (1994: 246) makes a clearer distinction regarding the role of imagination in history when he claims that although the work of a novelist and a historian are both works of imagination, 'the historian's picture is meant to be true'. In the study of the past, historians use historical imagination as a way to connect the available evidence, always taking into consideration the historical context. In this process, historians are responsible both for the connections they make and the evidence they use.

Historical empathy is also a disposition in the sense that understanding people in the past demands respect for them and care to understand them and their situation. 
Peter Lee (2005: 47) points out that although historical empathy is a cognitive act, this does not mean that:

we do not want our students to care about people in the past. If they treat people in the past as less than fully human and do not respond to those people's hopes and fears, they have hardly begun to understand what history is about.

Lack of undestanding, such as seeing people in the past as cognitively or morally inferior, is likely to lead to explanations of their different behaviour as being the result of these perceived shortcomings. Similarly, if we do not care to understand people in the past, we lack any incentive for moving beyond superficial explanations. As Barton and Levstik (2004: 228) rightly put it, 'Why would anyone expend energy trying to understand historical perspectives if they had no care or concern for the lives and experiences of people in the past?'

This is something that we strive to do not only for those whom we like or for whom we feel pity, but also for those who did things with which we disagree, and those who we consider to be wrongdoers or even to be perpetrators of evil. For David Sylvester, this is a major distinction between the cognitive act he named historical empathy and sympathy. As he explains:

We want to learn about Hitler. I don't want people to sympathise with Hitler, but youngsters ought to understand something of his background - why he was led to such views and in that sense they can empathise with at least why he took the actions he did. (Sheldon, 2009a: 27)

Furthermore, as Barton and Levstik (2004: 240) argue, the danger of sympathizing instead of empathizing with people in the past can be avoided 'as long as educators recognize that care is intimately bound up with tools such as perspective recognition, inquiry, or various kinds of narrative'.

Closing this section, it should be pointed out that although today there is a consensus about some of the key aspects of what understanding people in the past entails, such as the importance of knowledge about people's ideas, beliefs and historical context, authors in the field of history education have not reached agreement on other aspects. For example, the role of emotions and the affective aspects of historical empathy is still a key issue of disagreement (Barton and Levstik, 2004; Endacott and Brooks, 2013; Foster, 2001; Perikleous, 2014). However, as mentioned earlier, this section has aimed to define how historical empathy is approached in this study, rather than to provide a detailed argument in favour of this specific approach.

\section{The study}

This article reports on a qualitative collective case study of students' and teachers' ideas of historical empathy. The study aimed to investigate: (1) the ideas of and about historical empathy held by Greek Cypriot primary school students; (2) the ideas of and about historical empathy held by Greek Cypriot primary teachers; and (3) teachers' ideas about teaching historical empathy, and the degree to which their ideas about empathy and teaching the concept manifest in their teaching of history. This article reports only on the study's investigation of students' ideas.

Apropos this aspect, the study aimed to map primary students' ideas of historical empathy and to identify possible differences according to students' ages and the temporal and cultural distance between them and the practices that they were asked 
to explain. It also aimed to explore students' ideas about historical empathy, and more specifically their ideas about differences in empathic explanations. As with any other school subject, students come to history classes carrying their own ideas about the world and human behaviour. These ideas develop from a very young age and have a powerful effect on the integration of new concepts and understandings (Bransford et al., 2000; Lee, 2005). Although students' preconceptions can be helpful on many occasions, on many others they can be problematic, since ideas from everyday life cannot always be applied in the study of history. Failing to identify and understand students' existing ideas and assumptions may distort the construction of historical knowledge, and students 'may fail to grasp the new concepts and information that are taught, or they may learn them for purposes of a test but revert to their preconceptions outside the classroom' (Bransford et al., 2000: 14-15). It is essential to be aware of our students' existing ideas in order to be able either to build on them or to overturn them, so that we can help them to develop more powerful ones.

Research shows that students hold a variety of ideas that reveal different degrees to which they take into consideration past agents' beliefs, ideas and context when they try to explain behaviour in the past (Ashby and Lee, 1987; Berti et al., 2009; Cooper, 2007; Dickinson and Lee, 1978, 1984; Huijgen et al., 2014; Lee and Ashby, 2001; Lee et al., 2001; Perikleous, 2011; Shemilt, 1984). Students who are taught in ways that explicitly aim to develop their ideas of historical empathy are more likely to hold more sophisticated ideas than those who are not (Lee et al., 2001; Lee and Ashby, 2001; Shemilt, 1980). Older students are also more likely to hold more sophisticated ideas than younger ones (Berti et al., 2009; Lee and Ashby, 2001; Huijgen et al., 2014). Furthermore, past studies suggest that students provide better empathic explanations when they explain behaviours that took place within a historical context about which they have been taught (Ashby and Lee, 1987; Downey, 1995; Yeager and Doppen, 2001). Finally, research shows that students are often not able to distinguish between the historian's and the historical agent's point of view and the knowledge of the latter's situation (Ashby and Lee, 1987; Dickinson and Lee, 1978; Dulberg, 2002).

In the context of Greek Cypriot education, the field of history education is under-researched and students' ideas of historical empathy (or any other second-order concept) are unexplored. This is mainly due to the absence of a community of history education teachers and researchers, and also due to the fact that the prevailing view of history education sees it as a means to convey substantive knowledge and promote social values (Perikleous, 2010, 2015b; Klerides and Zembylas, 2017). In light of this, research about students' and teachers' understanding of second-order concepts (in this case, historical empathy) is needed in order to inform discussions and consequently educational policy in the area of history education in the Greek Cypriot education system. Finally, this kind of research responds to the expressed need for 'more work across different cultures [that] may shed further light on the currency of similar sets of ideas, and their stability in different educational and social environments' (Lee and Ashby, 2001: 45).

The sample for the study was drawn from two primary schools in Nicosia, Cyprus; 68 students aged between 9 and 12 from five classes participated. The selected age range of the sample covers the whole of students' formal history education in Greek Cypriot primary schools (Years 3 to 6). The teachers' sample consisted of the five teachers who taught history in the sample classes.

In the last few years there has been a process of reform in the teaching of history in Greek Cypriot schools, moving towards disciplinary approaches, but so far the changes are limited to the official texts of the history curriculum. The majority 
of the teaching material provided by the Ministry of Education and Culture follows a traditional approach of conveying factual knowledge, without any provision for developing disciplinary understanding, and teachers do not have substantial training opportunities that would allow them to develop their pedagogical content knowledge in terms of disciplinary approaches to teaching the subject. As a result, the majority of educators still use the traditional teaching approaches dictated by the available teaching material (Perikleous, 2011, 2015a, 2015b).

Furthermore, interviews with the teachers of the classes that participated in the study, and observations of their teaching of history, reveal that their teaching does not aim to develop their students' understanding of how to explain past behaviour. It is therefore likely that the students who participated in this study were not taught in ways that aim to develop historical empathy.

Pen-and-paper tasks, semi-structured interviews and classroom observations were used as data generation instruments. Four different tasks, asking the same eight open-ended questions about healing ceremonies related to religious beliefs, were used (see Appendix). Each student and teacher completed two of the tasks. Some of the students and all of the teachers were also interviewed. Classroom observations were also conducted in order to investigate aspects of teachers' practices in topics that involve understanding past behaviour.

Two of the tasks referred to past practices (of the ancient Greeks and ancient Maya), and two of them to practices that are still being used today by Orthodox Christians and Muslims. The study of ancient Greek civilization (religious beliefs, everyday life, social organization) takes up a substantial part of the Year 3 and Year 4 history curriculum, while the ancient Mayan civilization is not part of the prescribed content of the curriculum. The selection of healing ceremonies used by ancient Greeks and ancient Maya was made in order to allow the exploration of differences in participants' explanations according to their familiarity with the historical context of the practices. The selection of an Orthodox Christian ceremony and a Muslim one that are still practised today was made in order to allow the exploration of differences according to cultural distance between the participants and the practices in question, since all student participants were Orthodox Christians. Finally, the comparison between responses to practices in the present and practices in the past would allow the exploration of differences according to temporal distance.

Data were analysed using an inductive coding process associated with grounded theory techniques of analysis (Charmaz, 2006; Glaser and Straus, 1967). Students' and teachers' responses were initially coded line by line in order to produce codes that represented ideas in their simplest forms (not analysable in terms of combinations of simpler ones). After the production of initial codes, the ones that seemed to have similar content were grouped to form categories of responses. Following this phase, it became apparent that the categories of responses could be organized into broader groups of ideas (types of ideas) about five different topics: (1) ideas about why people chose the practice in question; (2) ideas about the group of people who exercised the practice; (3) ideas about the practice; (4) ideas about whether the participants in the study would follow the practice if they belonged to the group in question; and (5) ideas about the responses of other participants (whether other participants answered the same way, and why). 


\section{Students' ideas when explaining the choice of practice}

Because of the limited space available, and also because this is an ongoing study, this article will only discuss the types of ideas about why people chose the practice in question as these were expressed by students in the tasks that referred to past practices (those of ancient Greeks and ancient Maya). This discussion relates to the first aim of the study: to investigate the ideas of and about historical empathy held by Greek Cypriot primary school students.

The third phase of coding described above produced eight types of explanations in terms of how students explained the choice of practice:

1. life forms

2. beliefs

3. knowledge and intentions

4. lack of other options

5. deficit ideas/knowledge/means

6. non-explanations

7. lack of information

8. minor codes.

The life forms type of explanations include responses that referred to the practice as being part of the group's way of life or made sense for that specific time. For example, Kendra (Year 6) claimed that if she was an ancient Maya, she 'would choose it because it would be the treatment of the tribe in which I would belong', while Barry (Year 6) claimed that 'I find it strange because we are in the twenty-first century. For them [the ancient Maya], however, it was something that made sense.'

Many responses explained the choice of the practice by reference to people's beliefs. Some of them referred to beliefs in general (for example, 'Because they [the ancient Greeks] believed that it was probably the only one that could cure them' Asoko (Year 5)). However, the majority of these responses explicitly referred to religious beliefs. In some of the responses, these beliefs were considered to be correct. Sara (Year 6), for example, argued that 'their way was in general correct; to pray for someone to get well. It is correct to cast away the evil spirits.' In other cases, however, these beliefs were considered to be false. This can be observed in Joe's (Year 3) response. He disagreed with the ancient Maya's choice of treatment because 'the god was fake, and if you say different words the patient won't get well'. Finally, some responses referred to religious beliefs as simply being different from those of the student. For example, Clark (Year 6) claimed that the ancient Maya chose the specific practice 'because they believed in different gods than we do, and they believed that they would help them'.

There were also responses that explained the choice of practice by reference to specific knowledge and intentions. In some cases, responses suggested that this is knowledge that is still valid today (for example, the ancient Greeks 'choose this treatment to relax their system so the medicine and the doctor's instructions later can be done easier, faster and more aptly' - Oliver (Year 6)), while others argued that this was a choice based on empirical evidence of the treatment's effectiveness (for example, 'I think they [the ancient Maya] chose this treatment because it cured them, and they never got sick again' - Dale (Year 3)).

Responses that referred to the lack of other options explained the choice by focusing on the fact that the practice was the only or the best one available to them. Samantha (Year 3) explained that ancient Greeks chose the specific treatment because she did not think 'that there were any other treatments', while Arya (Year 3) wrote that 
if she was an ancient Maya, she 'would choose it because back then I wouldn't have any other choice'.

Another category of responses provided explanations for the choice of practice by references to deficits in terms of ideas, knowledge and means available to the group in question. For example, Deanna (Year 4) expressed her view of a deficit past by claiming that ancient Maya 'did not possess the rationality we have today ... they were not as rational as we are', while Daenerys (Year 3) argued that 'we don't have this way anymore because we are now more advanced'. Audrey (Year 3) claimed that ancient Greeks chose the practice in question 'because back then there were no medicines and they had to die in some occasions'.

The non-explanations category includes responses that did not provide an explanation for the choice of practice. Instead, they referred to personal preferences or used tautologies (for example, referring to the need for a cure as the reason for choosing the practice). For example, Jean-Luc (Year 4) suggested that the ancient Maya chose the practice because 'maybe they liked fasting and listening to prayers for the gods', while Dean (Year 5) responded by saying 'I think that one of the reasons was to get well.'

There are two more categories of responses: lack of information and minor codes. The former contains responses that referred to the need for more information without providing an explanation. For example, Stephen (Year 6) wrote: 'I don't agree or disagree with the choice of this treatment because we don't know if this treatment cured ancient Greeks or not.' The minor codes group was developed to identify responses that were rarely present and could not be grouped in any other code category.

Explanations by reference to beliefs and deficits were the ones most often used by the students. More than one-third of the total number of coded responses (36.4 per cent) explained the practice in terms of beliefs held by the group in question, while 29.5 per cent referred to the group's deficits in terms of ideas, knowledge and means (see Table 1). These two types of explanation were also the ones more likely to be used at least once in the tasks. The majority of completed tasks contained explanations in terms of deficit (80 per cent) and beliefs (67 per cent) (see Table 2). Apart from references to lack of information, which essentially did not provide any explanation, responses that explained the choice of practice by reference to the life forms were the ones least used by the students. Only 3.8 per cent of the total number of coded responses fell into this type of explanation (see Table 1) and only 16.1 per cent of the completed tasks contained such responses (see Table 2).

Older students referred to a group's beliefs more often than younger students (see Table 2). The vast majority (84 per cent) of tasks completed by Year 6 students (12 years old) contained references to beliefs, and the same applies for most of the tasks (75 per cent) completed by Year 5 students (11 years old). Tasks completed by Year 3 students ( 9 years old) and Year 4 students ( 10 years old) referred to beliefs less often. However, more than half of the completed tasks in Year 4 (62.5 per cent) and almost half of those completed by Year 3 ( 46.7 per cent) contained references to this specific type of explanation. This is the only type of explanation for which an agerelated pattern can be observed.

All types of explanation can be observed in completed tasks by all age groups (see Table 2). The only exception is Year 4, where completed tasks contain references to only four main types (beliefs, lack of other options, deficit and non-explanations). However, this is possibly due to the small number of tasks about past practices completed by that age group (only eight tasks). 
Table 1: Responses coded by type of explanation

\begin{tabular}{lcc}
\hline Type of explanation & Coded responses & $\%$ \\
\hline Life forms & 21 & 3.8 \\
Beliefs & 200 & 36.4 \\
Knowledge, intentions & 53 & 9.7 \\
Deficit ideas, knowledge, means & 162 & 29.5 \\
Lack of other options & 69 & 12.6 \\
Non-explanations & 22 & 4.0 \\
Lack of information & 8 & 1.5 \\
Minor codes & 14 & 2.6 \\
Total & $\mathbf{5 4 9}$ & 100 \\
\hline
\end{tabular}

Table 2: Percentage of completed tasks containing references to a type of explanation, by age group

\begin{tabular}{lccccc}
\hline & $\begin{array}{c}\text { Year } \mathbf{3} \\
\text { Type of explanation }\end{array}$ & $\begin{array}{c}\text { Year 4 } \\
(\%)\end{array}$ & $\begin{array}{c}\text { Year 5 } \\
(\%)\end{array}$ & $\begin{array}{c}\text { Year 6 } \\
\text { (\%) }\end{array}$ & $\begin{array}{c}\text { All age } \\
\text { groups } \\
\text { (\%) }\end{array}$ \\
\hline Life forms & 16.7 & 0 & 16.7 & 20 & 16.1 \\
Beliefs & 46.7 & 62.5 & 75 & 84 & 66.7 \\
Knowledge, intentions & 36.7 & 0 & 33.3 & 20 & 27.6 \\
Deficit ideas, knowledge, means & 83.3 & 100 & 58.3 & 92 & 80.5 \\
Lack of other options & 36.7 & 62.5 & 37.5 & 60 & 46 \\
Non-explanations & 30 & 12.5 & 16.7 & 12 & 19.5 \\
Lack of information & 0 & 0 & 4.2 & 4 & 2.3 \\
Minor codes & 10 & 25 & 16.7 & 12 & 13.8 \\
\hline
\end{tabular}

Although the types of explanations that emerged from the data analysis of this study are not identical to the ones suggested by other studies, they clearly correspond to the same continuum of ideas. As mentioned earlier, this continuum contains different degrees to which the ideas and beliefs of people in the past and the context in which they lived are taken into consideration.

As in previous studies (Ashby and Lee, 1987; Cooper, 2007; Dickinson and Lee, 1978, 1984; Lee and Ashby, 2001; Lee et al., 2001; Perikleous, 2011; Shemilt, 1984), presentism is a main feature in students' responses in the form of: (1) explaining past practices as the result of deficits in terms of ideas, knowledge and means; and (2) not acknowledging the ways in which people in the past and/or their situation were different. Wineburg (2001) claims that this is a natural way of thinking, and a way of thinking that requires little effort. It is the idea of a familiar past that is simple and speaks directly to us without the need for any translation, a past that is culturally homogeneous with the present, only inhabited by people who were either less intelligent and rational than people today, or who lacked in terms of knowledge and means.

The idea of a deficit past is also evident in studies that investigate other aspects of students' historical thinking (Barton, 1996, 2008; Levstik, 2008). This flawed past seems to be the result of a combination of presentism and students' idea that people in the past did not have what people in the present have in terms of rationality, 
technology and knowledge, and it is reinforced by the way children are introduced to the differences between the past and the present (by family, by society in general and, in many cases, by school) and by prevailing ideas about progress (Lee and Ashby, 2001; Lee, 2005).

Only a few students used explanations that considered the practices in question as parts of a group's particular way of life. Instead, in most of the cases where differences in historical context are acknowledged, presentism was expressed as explanations in terms of how modern people would have behaved in that situation. Students who operate with these ideas are not able to distinguish between their own and the historical agents' points of view and knowledge of the particular situation upon which the historical agents were acting (Ashby and Lee, 1987; Dickinson and Lee, 1978; Dulberg, 2002; Perikleous, 2011). Thus, they explain past practices by employing personal projections and ignoring the historical agents' point of view.

Although, as in previous studies (Lee and Ashby, 2001), older students were more likely to use explanations related to the groups' beliefs, in this study, even younger students referred to the groups' beliefs quite often. Thus, one could argue that this is a deviation from previous investigations, which assign these types of explanations to higher levels of ideas of historical empathy (Dickinson and Lee, 1978; Lee et al., 2001; Perikleous, 2011; Shemilt, 1984). However, this can be explained by the fact that the descriptions of the practices provided by the tasks were explicit about their religious element (religious practices for treating diseases). This phenomenon can also be observed in previous studies. For example, in the Concepts of History and Teaching Approaches (CHATA) project (Lee and Ashby, 2001), students of all ages referred to beliefs more often when the practice they were asked to explain was related to religion (in this case, Saxon trial by ordeal). In a later study in which students were also asked to explain Saxon trial by ordeal (being explicitly informed in the task about its connection with religious beliefs at the time), almost all students referred to beliefs in their explanations (Berti et al., 2009). In light of this, it seems that the individual characteristics of specific behaviour, and students' background knowledge about it, affect their explanations.

Finally, the fact that the different types of explanations identified in this study can be observed in all age groups confirms the findings of previous studies, according to which ideas held by students at any given age vary (Berti et al., 2009; Dickinson and Lee, 1978; Lee et al., 2001; Perikleous, 2011; Shemilt, 1984). It also supports previous findings that suggest that in some cases younger students use ideas that are more sophisticated than the ones used by older students (ibid.). The latter is a phenomenon observed not only in the case of students' ideas of history, but also in their understanding of other subjects, such as mathematics (Cockcroft, 1982).

It should be pointed out that the above discussion is based only on the total number of responses coded under each type of explanation and the number of tasks that contain at least one reference to a type of explanation. A more detailed understanding of students' ideas will be achieved by further analysis in terms of the relative weight that specific types of explanation have in students' responses, and by comparison between tasks and how different task questions might elicit answers that reveal different kinds of ideas.

\section{Conclusions}

Although research suggests a range of possible alternative ideas among students, there is no way to determine the exact ideas held by students in a specific class in 
advance. This is because, as shown in this and previous studies, students within the same group are likely to operate with a variety of ideas. In terms of teaching practice, this means that we need to provide our students with opportunities to express their ideas and assumptions. Besides the implementation of appropriate teaching strategies, Dickinson and Lee (1978: 108) remind us that we need to create an environment that 'allow[s] children to bring out their misconceptions and false assumptions, without fear of adverse reaction from peers or teachers'. When problematic ideas are expressed, they should not become a target for correction by the teacher, but should be used as a topic of discussion in order to help students to develop more powerful ideas. In addition, this discussion, and interaction in general, should not be between the teacher and the class or individual students, but one in which students also argue and interact with each other.

The fact that primary students expressed sophisticated ideas, even at younger ages, contributes to the validity of claims that students in primary education can develop powerful ideas of historical empathy, and that it is the duty of education to pursue this aim. Educational systems (in terms of curricula, teaching materials and teaching practices) have to acknowledge this, and to place an emphasis on developing students' understanding of historical empathy and other second-order concepts.

History teaching should also acknowledge the strong influence of presentism, and aim to help students realize the ways in which the past and its people were different from the present (Barton and Levstik, 2004; Huijgen et al., 2014; Wineburg, 2001). Foster (2001) and Seixas (1993) claim that empathy exercises work well in situations that are unfamiliar (and even seem puzzling or paradoxical) to students. This helps them to distinguish the historical period they study from the present in which they live, and also initiates curiosity (Foster, 2001). In addition, Seixas (1993) suggests that it might be easier for students to understand historical distance when they encounter situations that do not seem similar to their own. Finally, Wineburg (2001) claims that the unfamiliar past (more distant in thought, social organization and time) allows us to realize our limitations in understanding it. These views resonate with a claim made earlier in this article: part of developing ideas of historical empathy is to see the distance between us and people in the past not as an obstacle, but as a necessary condition when trying to make sense of the past. Of course, analogies with the present are always useful to help students to understand some aspects of human behaviour in the past, but we should be careful to avoid assimilating actions, institutions and practices in the past to modern ones.

This study also reconfirmed students' tendency to interpret the past in deficit terms. As mentioned earlier, the idea of a deficit past is cultivated in many cases by education itself. Lee and Ashby (2001) claim that the most serious mistake is the use of a causal language that conveys the message that people in the past did things because they could not do what we do today. Hence, it is important to help students realize that people did what they did in the past because of what they knew and had, and not because of what they did not know and did not have compared to the present. In addition to employing strategies to overturn this misconception through teaching, there is also a need to review the available teaching material and educational policies in general in order to address those aspects that promote this problematic idea.

Finally, we should bear in mind that developing students' ideas of historical empathy, and disciplinary understanding in general, is not an easy task. It cannot be achieved with only a few classroom discussions and examples. We must return to these ideas again and again when appropriate, and with suitable materials. We must also be aware of the fact that we are not aiming to create mini-historians and 
that 'developing students' understanding of history is worthwhile without implying any grandiose claims' (Lee, 2005: 40). Teaching concepts is not an all-or-nothing situation, but a process of continual development of more sophisticated ideas that will help our students to understand the past and its people, and be able to use this understanding to make sense of their own world.

\section{Notes on the contributor}

Lukas Perikleous is a primary school teacher. He also teaches history education and social studies as a part-time teaching fellow at the Department of Education, University of Cyprus. His research interests include children's and adults' ideas of historical empathy, the political and social aspects of history education, the teaching of controversial and sensitive issues in history, and the role of ICT and technologies of entertainment in history education.

\section{Appendix}

\section{Description of pen-and-paper tasks}

Each pen-and-paper task contained a short description of a religious ceremony used as a healing practice by two groups in the past (ancient Greeks and ancient Maya) and two groups in the present (Orthodox Christians and Muslims). These descriptions provided information about how the ceremony was/is performed and how it helped/ helps sick people according to the group in question.

This description was followed by eight open-ended questions. Six of the questions generated the data discussed in this article:

1. Why do you think these people chose this treatment when sick? Explain your answer as fully as you can.

2. Are there any other reasons for why these people sought this kind of treatment except those you mentioned when answering Question 1?

3. Is there anything that you find strange about the fact that these people chose this kind of treatment when sick? If yes, why do you find it strange? Explain your answer as fully as you can.

4. Do you agree or disagree with these people's choice of treatment? Why? Explain your answer as fully as you can.

5. If you were a member of the group of people, would you choose this kind of treatment when sick? Why? Explain your answer as fully as you can.

6. Why don't we do the same thing when we are sick today? Explain your answer as fully as you can.

\section{References}

Ashby, R. and Lee, P. (1987) 'Children's concepts of empathy and understanding in history'. In Portal, C. (ed.) The History Curriculum for Teachers. London: Falmer Press, 62-88.

Barton, K. (1996) 'Narrative simplifications in elementary students' historical thinking'. In Brophy, J. (ed.) Teaching and Learning History (Advances in Research on Teaching 6). Greenwich, CT: JAI Press, 56-60.

Barton, K.C. (2008) '"Bossed around by the queen": Elementary students' understanding of individuals and institutions in history'. In Levstik, L.S. and Barton, K.C. Researching History Education: Theory, method, and context. New York: Routledge, 159-82. 
Barton, K.C. and Levstik, L.S. (2004) Teaching History for the Common Good. Mahwah, NJ: Lawrence Erlbaum Associates.

Berti, A.E., Baldin, I. and Toneatti, L. (2009) 'Empathy in history: Understanding a past institution (ordeal) in children and young adults when description and rationale are provided'. Contemporary Educational Psychology, 34 (4), 278-88.

Boddington, T. (1980) 'Empathy and the teaching of history'. British Journal of Educational Studies, 28 (1), 13-19.

Bransford, J.D., Brown, A.L. and Cocking, R.R. (eds) (2000) How People Learn: Brain, mind, experience, and school. Washington, DC: National Academy Press.

Charmaz, K. (2006) Constructing Grounded Theory: A practical guide through qualitative analysis. London: SAGE Publications.

Cockcroft, W.H. (1982) Mathematics Counts: Report of the Committee of Inquiry into the Teaching of Mathematics in Schools. London: Her Majesty's Stationery Office.

Collingwood, R.G. (1994) The Idea of History. Rev. ed. Oxford: Oxford University Press.

Cooper, H. (2007) History 3-11: A guide for teachers. Oxford: David Fulton Publishers.

Dickinson, A.K. and Lee, P.J. (1978) 'Understanding and research'. In Dickinson, A.K. and Lee, P.J. (eds) History Teaching and Historical Understanding. London: Heinemann, 94-120.

Dickinson, A.K. and Lee, P.J. (1984) 'Making sense of history'. In Dickinson, A.K., Lee, P.J. and Rogers, P.J. (eds) Learning History. London: Heinemann, 117-53.

Downey, M.T. (1995) 'Perspective taking and historical thinking: Doing history in a fifth-grade classroom'. Paper presented at the American Educational Research Association (AERA) Annual Meeting, San Francisco, 18-22 April 1995.

Dulberg, N. (2002) 'Engaging in history: Empathy and perspective-taking in children's historical thinking'. Paper presented at the American Educational Research Association (AERA) Annual Meeting, New Orleans, 1-5 April 2002.

Endacott, J. and Brooks, S. (2013) 'An updated theoretical and practical model for promoting historical empathy'. Social Studies Research and Practice, 8 (1), 41-58.

Foster, S.J. (2001) 'Historical empathy in theory and practice: Some final thoughts'. In Davis, O.L., Yeager, E.A. and Foster, S.J. (eds) Historical Empathy and Perspective Taking in the Social Studies. Lanham, MD: Rowman and Littlefield, 167-82.

Gadamer, H.-G. (2004) Truth and Method. Trans. Weinsheimer, J. and Marshall, D.G. 2nd ed. New York: Continuum.

Glaser, B.G. and Strauss, A.L. (1967) The Discovery of Grounded Theory: Strategies for qualitative research. New York: Aldine.

Harris, R. and Foreman-Peck, L. (2004) '"Stepping into other people's shoes": Teaching and assessing empathy in the secondary history curriculum'. International Journal of Historical Learning, Teaching and Research, 4 (2), 98-111.

Huijgen, T., Van Boxtel, C., Van de Grift, W. and Holthuis, P. (2014) 'Testing elementary and secondary school students' ability to perform historical perspective taking: The constructing of valid and reliable measure instruments'. European Journal of Psychology of Education, 29 (4), 653-72.

Klerides, E. and Zembylas, M. (2017) 'Identity as immunology: History teaching in two ethnonational borders of Europe'. Compare: A Journal of Comparative and International Education, 47 (3), 416-33.

Knight, P. (1989) 'Empathy: Concept, confusion and consequences in a national curriculum'. Oxford Review of Education, 15 (1), 41-53.

Lee, P.J. (1984) 'Historical imagination'. In Dickinson, A.K., Lee P.J. and Rogers P.J. (eds) Learning History. London: Heinemann Educational, 85-116.

Lee, P.J. (2005) 'Putting principles into practice: Understanding history'. In Donovan, M.S. and Bransford, J.D. (eds) How Students Learn: History, mathematics, and science in the classroom. Washington, DC: National Academies Press, 31-77.

Lee, P. and Ashby, R. (2001) 'Empathy, perspective taking, and rational understanding'. In Davis, O.L., Yeager, E.A. and Foster, S.J. (eds) Historical Empathy and Perspective Taking in the Social Studies. Lanham, MD: Rowman and Littlefield, 21-50.

Lee, P., Dickinson, A. and Ashby, R. (2001) 'Children's ideas about historical explanation'. In Dickinson, A., Gordon, P. and Lee, P. (eds) International Review of History Education: Volume 3: Raising standards in history education. London: Woburn Press, 97-115.

Lee, P. and Shemilt, D. (2011) 'The concept that dares not speak its name: Should empathy come out of the closet?'. Teaching History, 143, 39-49. 
Levstik, L.S. (2008) 'The relationship between historical response and narrative in a sixth-grade classroom'. In Levstik, L.S. and Barton, K.C. Researching History Education: Theory, method, and context. New York: Routledge, 10-29.

Low-Beer, A. (1989) 'Empathy and history'. Teaching History, 55, 8-12.

Lowenthal, D. (1985) The Past is a Foreign Country. Cambridge: Cambridge University Press.

Perikleous, L. (2010) 'At a crossroad between memory and thinking: The case of primary history education in the Greek Cypriot educational system'. Education 3-13: International Journal of Primary, Elementary and Early Years Education, 38 (3), 315-28.

Perikleous, L. (2011) 'Why did they treat their children like this? A case study of 9-12 year-old Greek Cypriot students' ideas of historical empathy'. In Perikleous, L. and Shemilt, D. (eds) The Future of the Past: Why history education matters. Nicosia: Association for Historical Dialogue and Research, 217-51.

Perikleous, L.N. (2014) 'Deanna Troi and the TARDIS: Does historical empathy have a place in education?'. International Journal of Historical Learning, Teaching and Research, 12 (2), 22-30.

Perikleous, L.N. (2015a) 'A "game" of identities: Debates over history in Greek Cypriot education'. In Cooper, H. and Nichol, J. (eds) Identity, Trauma, Sensitive and Controversial Issues in the Teaching of History. Newcastle upon Tyne: Cambridge Scholars Publishing, 58-80.

Perikleous, L. (2015b) 'A brave new world: History education reform in the Greek-Cypriot educational system'. In Chapman, A. and Wilschut, A. (eds) Joined-Up History: New directions in history education research. Charlotte, NC: Information Age Publishing, 161-82.

Retz, T. (2015) 'A moderate hermeneutical approach to empathy in history education'. Educational Philosophy and Theory, 47 (3), 214-26.

Seixas, P. (1993) 'Popular film and young people's understanding of the history of Native Americanwhite relations'. The History Teacher, 26 (3), 351-70.

Sewell, W.H. (2005) Logics of History: Social theory and social transformation. Chicago: University of Chicago Press.

Sheldon, N. (2009a) 'Interview with David Sylvester'. History in Education, 7 July. Online. https:// tinyurl.com/y4ycwuxa (accessed 7 July 2019).

Sheldon, N. (2009b) 'Interview with Peter Lee and Ros Ashby'. History in Education, 3 September. Online. https://tinyurl.com/yynb4a53 (accessed 7 July 2019).

Shemilt, D. (1980) History 13-16 Evaluation Study. Edinburgh: Holmes McDougall.

Shemilt, D. (1984) 'Beauty and the philosopher: Empathy in history and classroom'. In Dickinson, A.K., Lee, P.J. and Rogers, P.J. (eds) Learning History. London: Heinemann, 39-84.

Shemilt, D. (2016) Personal communication, email (13 April).

Wineburg, S. (2001) Historical Thinking and Other Unnatural Acts: Charting the future of teaching the past. Philadelphia: Temple University Press.

Yeager, E.A. and Doppen, F.H. (2001) 'Teaching and learning multiple perspectives on the use of the atomic bomb: Historical empathy in the secondary classroom'. In Davis, O.L., Yeager, E.A. and Foster, S.J. (eds) Historical Empathy and Perspective Taking in the Social Studies. Lanham, MD: Rowman and Littlefield, 97-114.

Yeager, E.A. and Foster, S.J. (2001) 'The role of empathy in the development of historical understanding'. In Davis, O.L., Yeager, E.A. and Foster, S.J. (eds) Historical Empathy and Perspective Taking in the Social Studies. Lanham, MD: Rowman and Littlefield, 13-20. 